\title{
Perceptions and risky behaviors associated with Leptospirosis in an endemic area in a village of Ubon Ratchathani Province, Thailand.
}

\author{
Jaruwan Wongbutdee, Wacharapong Saengnill, Jutharat Jittimanee, Suwaporn Daendee
}

College of Medicine and Public Health, Ubon Ratchathani University, Thailand.

\begin{abstract}
Background: Leptospirosis, a disease caused by Leptospira species, a spirochaete bacterium that can develop in an appropriate environment and/or grow in human and/or animal hosts, is a serious problem for the Ministry of Public Health, Thailand. Objective: To investigate people's perceptions and behavioral risks regarding leptospirosis infection.

Methods: The cross-sectional descriptive study collected data in May, 2013. Data on individuals' perceptions and risky behaviors concerning leptospirosis were collected from 104 completed questionnaires.

Results: Regarding perceptions of leptospirosis, we found them to be at a high level (97.1\%) and risky behaviors regarding leptospirosis were reported at a moderate level $(74.0 \%)$. The study found no correlation between perceptions and risky behaviors regarding leptospirosis ( $\mathrm{r} 0.186$, p-value 0.059 ).

Conclusion: This study suggest that people in these areas have good knowledge about leptospirosis. However, some people have risky behavior associated with leptospirosis. Thus, a behavioral change campaign should be promoted to encourage people awareness of the dangers of such behavior.

Keywords: Perceptions, risky behaviors, leptospirosis.

DOI: http://dx.doi.org/10.4314/ahs.v16i1.23

Cite as: Wongbutdee J, Saengnill W, Jittimanee J, Daendee S. Perceptions and risky behaviours associated with Leptospirosis in an endemic area in a village of Ubon Ratchathani Province, Thailand. Afri Health Sci. 2016;16(1): 170-176. http:/ / dx.doi.org/10.4314/abs.v16i1.23
\end{abstract}

\section{Introduction}

Leptospirosis is a disease caused by a spirochaete bacterium called Leptospira spp and is a significant problem for the Ministry of Public Health, Thailand. The disease can exist in human and animal hosts and in soil, water, and mud $^{1-2}$. Generally, Leptospira spp have survived in an aqueous environment for extended periods after they have been shed from the renal tubules from animal reservoirs ${ }^{3}$. Humidity, temperature, and rainfall are important factors for the survival of Leptospira ${ }^{4}$. Khairani-Bejo et $\mathrm{al}^{5}$ found river water with $\mathrm{pH}$ levels of between 6.7 and 7.3 and with a dissolved solid salt content of between 3.78\% and 3.85\% conducive for Leptospira.

Infection can be transmitted from animals to humans via exposure of water resources, soil, mud, grass, and feeds to urine, milk, embryonic tissue, secretions from female animals, and semen from males. This contamination may be via activities associated with leisure, such as swimming, farm work, water sports and/or adven-

\section{Correspondence author: \\ Jaruwan Wongbutdee, College of Medicine and Public Health, Ubon Ratchathani University, Thailand 34190. \\ Telephone: +66867992498 \\ Email: jw_beer@yahoo.com}

ture travel $^{6-8}$. In addition, humans can be infected by eating food or drinking water contaminated by Leptospira spp ${ }^{9}$.Unprotected persons can get infected by Leptospira through the bacterium entering the body through broken skin, via the mucous membranes of the eyes, nose, and mouth, and by consuming contaminated food and/or water'. Bolin ${ }^{10}$ reported that leptospirosis can be transmitted from mothers to babies through breast milk.

The persons most at-risk of leptospirosis disease infection are those who have careers and/or lives closely related to animals, or people involved in activities that require them to be exposed to water for a long time.This study aimed to investigate the perceptions and behavioral at risk for leptospirosis are those persons working and/or living in high-risk situation in Thailand.

\section{Methods \\ Data collection}

The cross-sectional descriptive study was conducted in Phraroj village, Nong Chang sub-district, Muang Samsib district, Ubon Ratchathani province in May 2013. Phraroj is located at $15^{\circ} 33^{\prime} 43.49^{\prime \prime}$ north and $104^{\circ} 47^{\prime}$ 48.12" eastern part of Thailand. The study site contained 139 households and 352 people.

African Health Sciences Vol 16 Issue 1, March 2016 


\section{Participants}

The households were randomized $70 \%$ of all. Participants in the study were the heads of the households or representatives of the households who gave consent for their participation and had lived in the area for not less than six months. Data were collected by completion of questionnaires by the participants and a total of 104 questionnaires were returned.

\section{Measures}

The structured questionnaire was composed of: 1) a socio-demographic information section (8 items)

2) a section about perceptions of leptospirosis (16 items ). The question items in this section were analyzed via rating scales divided into either positive or negative questionnaire items. For positive items, they were rated from "agreed" (1) to "disagreed" (0). In contrast negative items were rated from "agreed" $(0)$ to "disagreed" (1). Interpretations of the results were based on the total scores of the respondents out of a total of 16 points. A score of 11 to 16 points was considered to be a high level of perception, 6 to 10 was regarded as at a moderate level, and 1 to 5 was interpreted as a low level. 3) a section about behavioral risks in regard to leptospirosis (16 items). The question items in this section were analyzed via rating scales divided into either positive or negative questionnaire items. For positive items, they required YES/NO answers, with affirmative answers receiving 1 point and negative answers receiving 0 points. In contrast negative items were rated from $\mathrm{YES}(0) / \mathrm{No}(1)$.

Interpretations were based on the scores out of a total of 16 . Scores of 11 to 16 were regarded as indicators of high-risk behaviors, 6 to 10 as signs of moderate risk behaviors, and 1 to 5 as displays of low-risk behavior.

The questionnaire's test validity by the use of Cronbach's alpha coefficient was 0.677 , and reliability of the content was assessed by two experts.

\section{Statistical analysis}

Data was analyzed by the use of frequencies, percentages, means, and standard deviations. The relationship between perceptions of and behavioral risks in regard to leptospirosis were investigated by the use of statistical analysis for the correlation coefficient of Pearson (Pearson's Product-Moment Correlation Coefficient) at a significance level of 0.05 .

\section{Results}

Data in relation to socio-demographic information of the respondents showed that $51.9 \%$ were female and $73.1 \%$ were married. The majority $(70.2 \%)$ had completed elementary school and lower. Most (63.5\%) had monthly revenues of under 5,000 baht and $83.7 \%$ were engaged in farming (Table 1).

Table 1 Numbers and percentages of socio-demographic information

\begin{tabular}{|c|c|c|}
\hline Socio-demographic information & $\begin{array}{c}\text { Number } \\
\text { (n) }\end{array}$ & $\begin{array}{c}\text { Percentages } \\
(\%)\end{array}$ \\
\hline \multicolumn{3}{|l|}{ Gender } \\
\hline Male & 50 & 48.1 \\
\hline Female & 54 & 51.9 \\
\hline \multicolumn{3}{|l|}{ Status } \\
\hline Single & 11 & 10.6 \\
\hline Married & 76 & 73.1 \\
\hline Divorced/widowed & 17 & 16.3 \\
\hline \multicolumn{3}{|l|}{ Education } \\
\hline Elementary and lower & 73 & 70.2 \\
\hline Secondary school & 12 & 11.5 \\
\hline High school & 11 & 10.6 \\
\hline Diploma & 3 & 2.9 \\
\hline Bachelor & 4 & 3.8 \\
\hline Graduate & 1 & 1.0 \\
\hline \multicolumn{3}{|l|}{ Monthly income } \\
\hline Lessthan 5,000 baht & 66 & 63.5 \\
\hline $5,000-10,000$ baht & 30 & 28.8 \\
\hline $10,000-20,000$ baht & 6 & 5.8 \\
\hline More than 20,000 baht & 2 & 1.9 \\
\hline \multicolumn{3}{|l|}{ Careers } \\
\hline Farmer & 87 & 83.7 \\
\hline General hired hand & 8 & 7.7 \\
\hline Merchant & 4 & 3.8 \\
\hline Government officer & 4 & 3.8 \\
\hline Other & 1 & 1.0 \\
\hline \multicolumn{3}{|l|}{ Perceptions of information about Leptospirosis } \\
\hline Got information from external sources & 101 & 97.1 \\
\hline Did not get information from external sources & 3 & 2.9 \\
\hline \multicolumn{3}{|l|}{ Animal husbandry } \\
\hline I breed animals such as dogs, cats, cows, buffalos, andpigs & 70 & 67.3 \\
\hline I do not breed animals & 34 & 32.7 \\
\hline \multicolumn{3}{|l|}{ Time per day for farming/plowing/sowing without shoes } \\
\hline Less than 6 hours & 70 & 67.3 \\
\hline More than 6 hours & 34 & 32.7 \\
\hline
\end{tabular}


Perceptions of information about leptospirosis were mostly received via public health volunteers and hos- pital staff $(94.2 \%)$, followed by community broadcast tower $(64.4 \%)$, radio $(57.7 \%)$, TV $(56.7 \%)$, respectively (Figure 1).

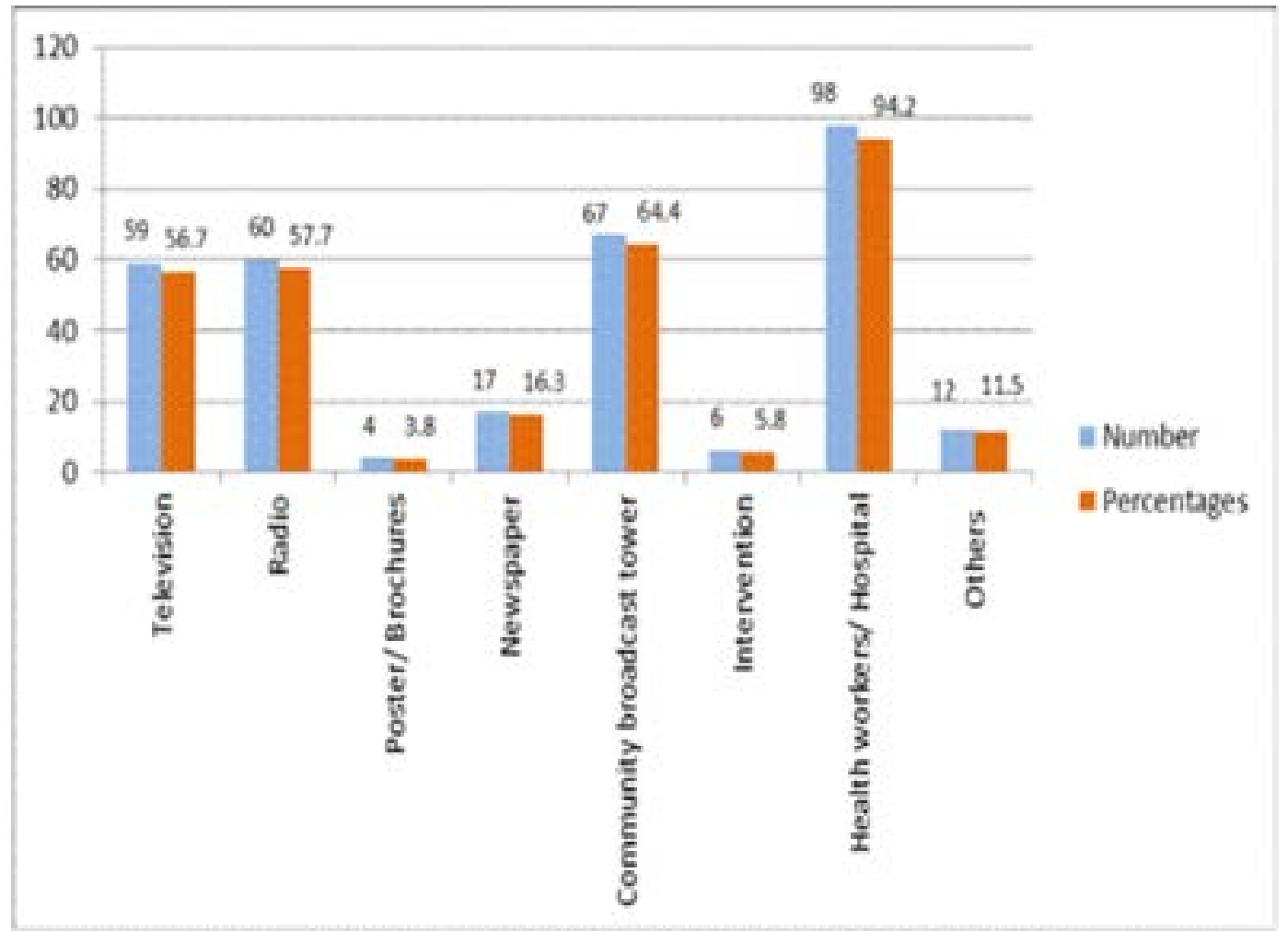

Figure 1 Sources of information about Leptospirosis

Data collected from the questionnaires regarding perceptions of leptospirosis mostly showed a high level
(97.1\%) (Figure 2). However, not all items conformed to this level, for example, only $48.1 \%$ agreed that farmers can be infected with leptospirosis (Table 2).

Table 2 Perceptions regarding Leptospirosis

\begin{tabular}{|c|c|c|}
\hline Perceptions regarding Leptospirosis & $\begin{array}{l}\text { Agree } \\
\text { n (\%) }\end{array}$ & $\begin{array}{l}\text { Disagree } \\
\text { n }(\%)\end{array}$ \\
\hline 1. Leptospirosis is caused by bacteria in rats' urine & $103(99.0)$ & $1(1.0)$ \\
\hline $\begin{array}{l}\text { 2. Leptospirosis is caused by bacteria in the urine of pigs, cattle, and } \\
\text { dogs }\end{array}$ & $77(74.0)$ & $27(26.0)$ \\
\hline 3. The cause of Leptospirosis is Leptospira & $81(77.9)$ & $23(22.1)$ \\
\hline 4. Leptospirosis occurs in the rainy season & $100(96.2)$ & $4(3.8)$ \\
\hline 5.The animals that spread the disease are rats, pigs, $c$ & $96(92.3)$ & $8(7.7)$ \\
\hline 6. Leptospirosis exists in water sources and canals & $100(96.2)$ & $4(3.8)$ \\
\hline 7.Wet soil is a source of Leptospirosis & $99(95.2)$ & $5(4.8)$ \\
\hline $\begin{array}{l}\text { 8. Leptospirosis infection can be caused by contact with the urine } \\
\text { of infected animals and contaminated water }\end{array}$ & $101(97.1)$ & $3(2.9)$ \\
\hline 9. Leptospirosis infection is caused by inhalation & $65(62.5)$ & $39(37.5)$ \\
\hline 10. Leptospirosis can only infect farmers * & $50(48.1)$ & $54(51.9)$ \\
\hline 11. The incubation period of Leptospirosis is 60 days $*$ & $38(36.5)$ & $66(63.5)$ \\
\hline 12. Leptospirosis can cause death & $99(95.2)$ & $5(4.8)$ \\
\hline $\begin{array}{l}\text { 13.The main symptoms of Leptospirosis include fever, severe } \\
\text { headache, and severe muscle pain, especially in the calf and femur }\end{array}$ & $103(99.0)$ & $1(1.0)$ \\
\hline $\begin{array}{l}\text { 14.Patients with severe Leptospirosis have such symptoms } \\
\text { asjaundice, acute liver failure, and acute kidney failure }\end{array}$ & $100(96.2)$ & $4(3.8)$ \\
\hline 15. Wearing of boots and gloves can prevent Leptospirosis & $103(99.0)$ & $1(1.0)$ \\
\hline $\begin{array}{l}\text { 16. Dead animals from areas affected by Leptospirosis or with } \\
\text { unknown causes of death should not be consumed }\end{array}$ & $90(86.5)$ & $14(13.5)$ \\
\hline
\end{tabular}




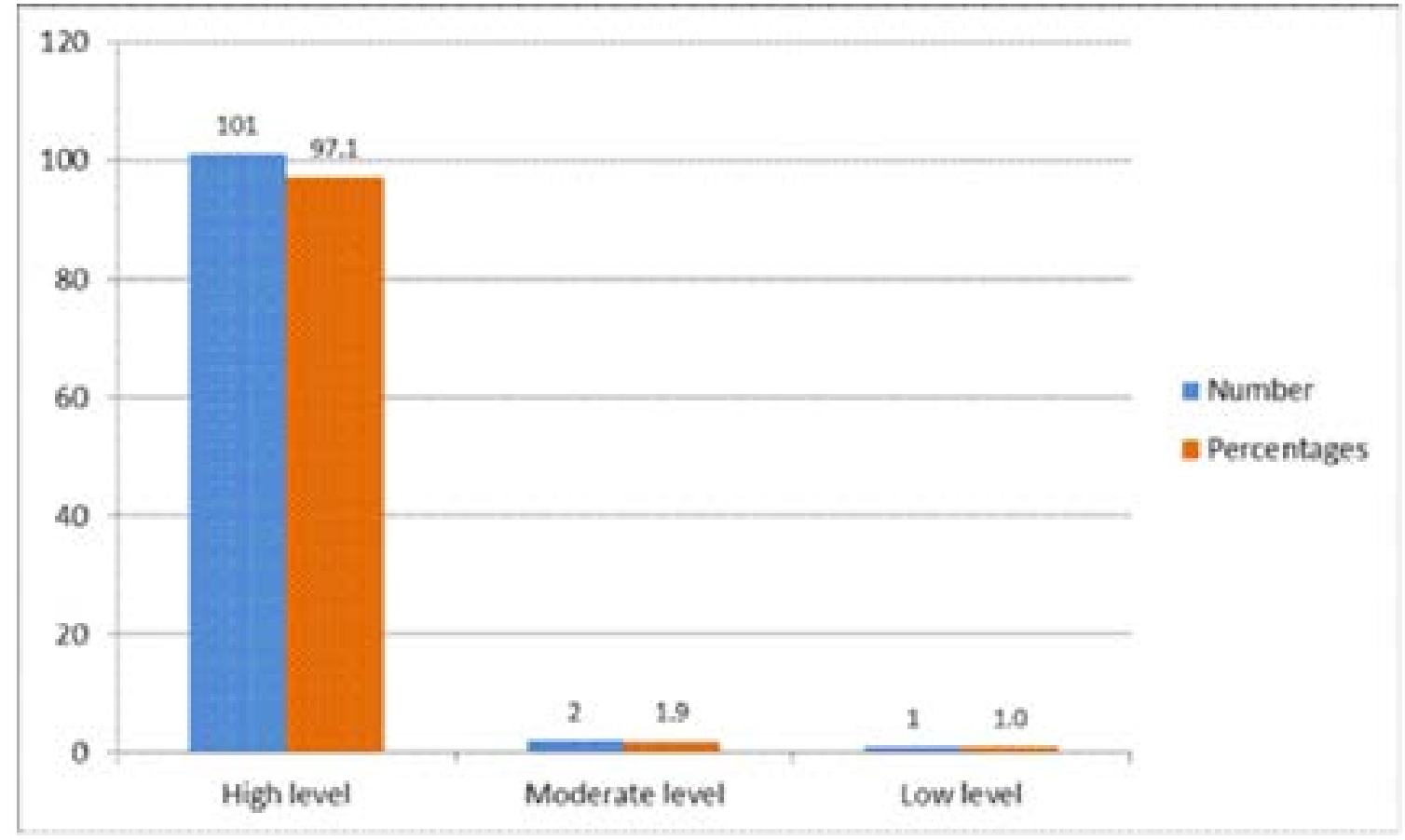

Figure 2 Levels of perception of Leptospirosis

Data collected from the questionnaires regarding be- moderate level of risk (74.0\%) and a high level of risk havioral risks involving leptospirosis mostly showed a (25.0\%) (Figure 3).

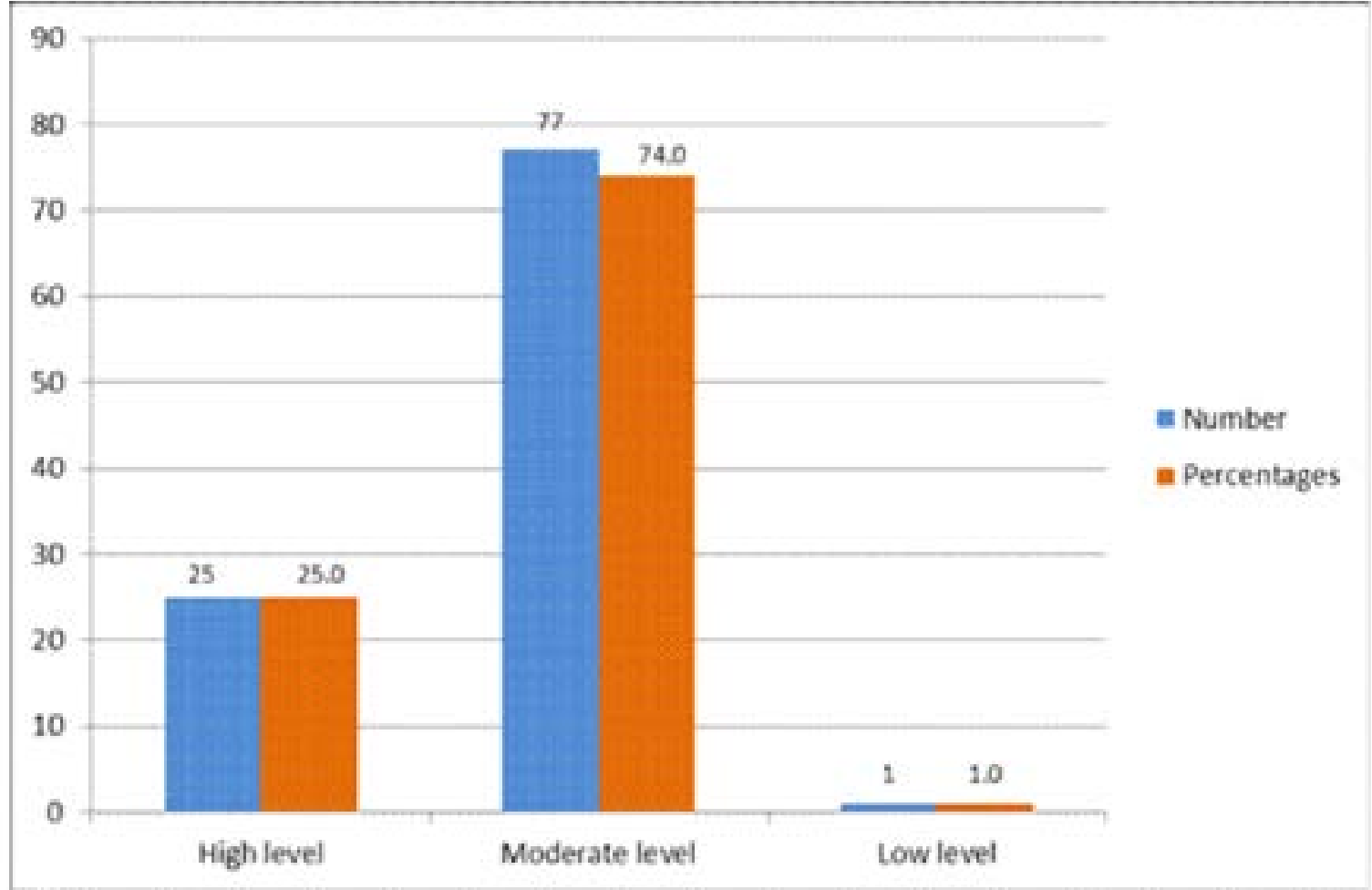

$9.15 .51) \quad 1.97$

Figu re 3 Levels of risk bchaviors regarding Leptospirosis 
High risk behaviors could be seen in responses to specific questions, such as not wearing foot protection when working $(88.5 \%)$, walking barefooted in mud while having leg wounds/scratches (59.6\%), and not draining waste water from stalls and/or houses (91.3\%) (Table 3). It was found that perceptions were not correlated with risk behaviors in regard to leptospirosis ( $\mathrm{r}$ 0.186, p-value 0.059).

\section{Table 3 Risk behaviors in relation to Leptospirosis}

\begin{tabular}{|c|c|c|}
\hline Risk behaviors in relation to Leptospirosis & $\begin{array}{c}\text { Yes } \\
\text { n }(\%)\end{array}$ & $\begin{array}{c}\text { No } \\
\text { n }(\%)\end{array}$ \\
\hline 1. You bring animals, such as cattle, pigs, dogs, and cats, to breed & $62(59.6)$ & $42(40.4)$ \\
\hline in your home & $29(27.9)$ & $75(72.1)$ \\
\hline 2. You get rid of animal feces from the animal husbandry area* & $9(8.7)$ & $95(91.3)$ \\
\hline 3. You drain waste water from stalls or house * & $104.0(0)$ & 0 \\
\hline 4. You wash your hands every time before and after eating * & $102(98.1)$ & $2(1.9)$ \\
\hline 5. You always eat clean and freshly cooked food * & $67(64.4)$ & $37(35.6)$ \\
\hline 6. You eat half-cooked meat or entrails of animals & $88(84.6)$ & $16(15.4)$ \\
\hline $\begin{array}{l}\text { 7. You always drink clean water (boiled water, tap water, } \\
\text { bottled water) * }\end{array}$ & $46(44.2)$ & $58(55.8)$ \\
\hline $\begin{array}{l}\text { 8. You bathe or soak in water sources, such as canals, swamps, } \\
\text { and creeks }\end{array}$ & $62(59.6)$ & $42(40.4)$ \\
\hline $\begin{array}{l}\text { 9. You trample in mud barefooted while havingwounds/scratches on } \\
\text { your legs and/or feet }\end{array}$ & $92(88.5)$ & $12(11.5)$ \\
\hline $\begin{array}{l}\text { 10. You do not wear boots while walking in water while farming } \\
\text { and/or gardening }\end{array}$ & $41(39.4)$ & $63(60.6)$ \\
\hline $\begin{array}{l}\text { 11. You are in contact urine of cattle, rats, and/or pigs every day } \\
\text { 12. You wash your body with clean water and soap immediately }\end{array}$ & $99(95.2)$ & $5(4.8)$ \\
\hline after walking in water, mud, and/or fields * & $19(18.3)$ & $85(81.7)$ \\
\hline 13. You dissect animals while wearing gloves * & $93(89.4)$ & $11(10.6)$ \\
\hline $\begin{array}{l}\text { 14. You wash your hands with clean water and soap aftertouching } \\
\text { dead bodies of animals * }\end{array}$ & $65(62.5)$ & $39(37.5)$ \\
\hline $\begin{array}{l}\text { 15. You control and eliminate rats in and around the house areas } \\
\text { through the use of cages, rat traps, and/or rat glue * } \\
16 \text {. You clean rubbish from the area around your house * }\end{array}$ & $90(86.5)$ & $14(13.5)$ \\
\hline
\end{tabular}

\section{Discussion}

Despite results showing that the participants' perceptions regarding leptospirosis were at a high level, there were some false perceptions held by the respondents. For example, $48.1 \%$ of respondents believed only farmers are affected by the disease. The Bureau of Epidemiology, Department of Disease Control ${ }^{11,12,13}$ presented data from 1 January 2013 to 19 October 2013, 2012, and 2011 that showed that this belief was incorrect. From 1 January 2013 to 19 October 2013, 2,230 patients suffered from leptospirosis resulting in 19 deaths. Of these, $56.0 \%$ were farmers, $22.4 \%$ were hired employees, and $9.5 \%$ were students. In 2012, 3,093 patients suffered from leptospirosis. Of these, $56.26 \%$ were farmers, $22.18 \%$ were hired employees, and $9.60 \%$ were students. In 2011, 4,237 leptospirosis patients were high in farmers (59.07\%), hired employees $(19.78 \%)$, and students $(10.05 \%)$. Interestingly, leptospirosis information was received mainly via public health volunteers and hospital staff, it included the knowledge related to the disease and prevention campaigns for instance getting rid of animal host, eating freshly cooked food, and drinking boiled water. Nevertheless, the continuation and expansion of the campaign activities alongside with disease intervention should be promoted to enhance the prevention skills of leptospirosis among high risk population. 
The risky behaviors in relation to leptospiroisis were found to be at the moderate $(74.0 \%)$ and high risk levels $(25 \%)$, and are considered inadequate for the prevention of leptospirosis. Such behaviors as not wearing foot protection while farming and/or gardening ( $\mathrm{Ta}$ ble 3) and spending more than six hours a day without footwear (Table 1) display this inadequacy, resulting in a high risk of leptospirosis. Some previous studies reported that prolonged barefooted exposure to water leads to high risk for contracting leptospirosis ${ }^{14-16}$. Levett $^{1}$ found that the disease my enter the body due to lengthy exposure to wet, muddy environments in which leptospira is likely to thrive.

The study found that there was no association between perceptions and behavioral risks associated with leptospirosis. Perceptions were high due to health promotion in the village but the villagers were still involved in highrisk behaviors concerning leptospirosis.

The study area was in a rural setting in which people were mainly engaged in farming. When working on the farm, they usually did not wear foot protection due to its inconvenience. Vanaporn et $\mathrm{al}^{17}$ and Chadsuthi et al ${ }^{18}$ found that leptospirosis spreads in the rainy season, a time that coincides with traditional practices in the study area of catching freshwater fish and using water from local ponds. Such behaviors and practices mean that health promotion campaigns need to be tailored to provide continual surveillance and efficient prevention of leptospirosis.

\section{Conclusion}

Appropriate perceptions and preventative behaviors regarding leptospirosis play important roles in monitoring the disease. As a result, health staff and relevant agencies must promote activities to encourage correct perceptions and risky behaviors that create healthy lifestyles for the minimization of leptospirosis.

\section{Acknowledgements}

This research was supported by Grants from the Office of Research Administration and Academic Services at Ubon Ratchathani University and Area-Based Collaborative Research Thailand Research Fund (TRF). The authors thank the staff of the Office of International Relations at Ubon Ratchathani University for assistance with English and the Phraroj Tambon Health Promoting Hospital, Ubon Ratchathani province for its collaboration.

\section{References}

1. Levett PN. Leptospirosis. Clin Microbiol Rev. 2001; 14(2): 296-326.

2. Adler B, Da la Pena Moctezuma A. Leptospira and leptospirosis. Vet Microbiol. 2010; 140(3-4): 287-96.

3. Tappero JW, Ashford DA, Perkins BA. Leptospira species (leptospirosis). In: Mandell GL, Bennett JE, Dolin R, eds. Principles and practice of infectious diseases. 5th ed. Vol 2. Philadelphia: Churchill Livingstone, 2000: 2495-501.

4. Astudillo VG, Hernández DW, Stadlin JP, Bernal LA, Rodríguez DA, Hernández MA. Comparative seroprevalence of Leptospira interrogans in Colombian mammals along a climatic gradient. J Zoo Wildl Med. 2012; 43(4): 768-75.

5. Khairani-Bejo, A. B. Bahaman S, Zamri-Saad M. and Mutalib A.R. The Survival of Leptospira interrogans Servovar Hardjo in the Malaysian Environment. Animal and Veterinary Advances. 2004; 3(3): 123-29.

6. Anderson DC, Folland DS, Fox MD, Patton CM, and Kaufmann AF. Leptospirosis: a common-source outbreak due to leptospires of the grippotyphosa serogroup. Am J Epidemiol. 1978; 107(6): 538-44.

7. Katz AR, Manea SJ, and Sasaki DM. Leptospirosis on Kauai: Investigation of a Common Source Waterborne Outbreak. Am J Public Health. 1991; 81(10): 13102.

8. Haake DA, Dundoo M, Cader R, Kubak BM, Hartskeerl RA, Sejvar JJ and Ashford DA. Leptospirosis, water sports, and chemoprophylaxis. Clin Infect Dis. 2002; 34(9).40-3

9. Cacciapouti B, Ciceroni L, Mafeei C, Di Stanislao F, Strusi P, Calegari L, Lupidi R, Scalise G, Cagnoni G, Renga G. A waterborne outbreak of leptospirosis. Am J Epidemiol. 1987; 126(3): 535-45.

10. Bolin CA, Koellner P. Human-to-human transmission of Leptospira interrogans by milk. J Infect Dis. 1988; 158(1): 246-7.

11. Bureau of Epidemiology, MOPH. Leptospirosis. National disease surveillance (report 506). http:// www.boe.moph.go.th/boedb/surdata/506wk/y56/en/ d43_4256_en.pdf. Accessed August, 2013.

12. Bureau of Epidemiology, MOPH. Leptospirosis. National disease surveillance (report 506). http://www. boe.moph.go.th/boedb/surdata/y56/d_occ_Lepto_56.rtf. Accessed August,2014.

13. Bureau of Epidemiology, MOPH. Leptospirosis. National disease surveillance (report 506). http://www. boe.moph.go.th/boedb/surdata/y55/d_occ_Lepto_55.rtf. Accessed August, 2014. 
14. Bovet P, Yersin C, Merien F, Davis CE, Perolat P. Factors associated with clinical leptospirosis: a population-based case-control study in the Seychelles (Indian Ocean). Int J Epidemiol. 1999; 28 (3): 583-90.

15. Sehgal SC. Epidemiological patterns of leptospirosis. Indian J of Med Microbiol. 2006; 24 (4): 310-311.

16. Sugunan A.P, Vijayachari P, Sharma S, Subarna R, Manickam P, Natarajaseenivasan K, Gupte MD, Sehqal SC. Risk factors associated with leptospirosis during an outbreak in Middle Andaman, India. Indian J Med Res. 2009; 133(1): 67-73.
17. Wuthiekanun V, Sirisukkarn N, Daengsupa P, Sakaraserane P, Sangkakam A, Chierakul W, Smythe LD, Symonds ML, Dohnt MF, Slack AT, Day NP, Peacock SJ. Clinical Diagnosis and Geographic Distribution of Leptospirosis, Thailand. Emerg Infect Dis. 2007; 13(1): 124-6.

18. Chadsuthi S, Modchang C, Lenbury Y, Iamsirithaworn S, Triampo W. Modeling seasonal leptospirosis transmission and association with rainfall and temperature in Thailand using 